\title{
Problematyka stosowania art. $819 \S 1$ k.c. do roszczenia o świadczenie wykupu w umowie ubezpieczenia na życie z ubezpieczeniowym funduszem kapitałowym
}

Celem artykułu jest rozważenie stosowania artykułu 819 kodeksu cywilnego do roszczenia o świadczenie wykupu w umowie ubezpieczenia na życie z ubezpieczeniowym funduszem kapitałowym. Autorka przedstawia analizę problemu z uwzględnieniem szerszego kontekstu dotyczqcego właściwości umowy ubezpieczenia na życie z ubezpieczeniowym funduszem kapitałowym oraz umowy ubezpieczenia na życie. Artykuł prezentuje również jakie sq korzyści uzyskane przez ubezpieczyciela w ramach zawieranych kontraktów. Przedstawiono dodatkowo rozważania dotyczace stosowania przepisów o bezpodstawnym wzbogaceniu do roszczeń o zapłatę wartości wykupu.

słowa kluczowe: ubezpieczenie na życie z ubezpieczeniowym funduszem kapitałowym, ubezpieczenie na życie, termin przedawnienia, umowa ubezpieczenia, świadczenia całkowitego lub częściowego wykupu

\section{Wprowadzenie}

W ostatnim czasie pojawiły się wạtpliwości odnoszące się do stosowania przepisu dotyczącego terminów przedawnienia roszczeń z umowy ubezpieczenia tzn. art. 819 § 1 k.c., do roszczenia o świadczenie wykupu z umowy ubezpieczenia na życie z ubezpieczeniowym funduszem kapitałowym, w szczególności roszczenia o zapłatę części wartości wykupu niewypłaconej w związku z postanowieniami o.w.u. uznanymi następnie za abuzywne. Jest to kwestia niezmiernie istotna dla wszystkich podmiotów funkcjonujących na rynku ubezpieczeniowym, ale przede wszystkim dla uprawnionych do świadczeń z tytułu zawartych umów. Należy jednak podkreślić, że zastosowanie określonego terminu przedawnienia roszczeń wpływa bezpośrednio na zobowiązania ubezpieczycieli wobec uprawnionych, którzy zawarli umowy ubezpieczenia na życie z ubezpieczeniowym 
funduszem kapitałowym, ale również na innych klientów zakładu ubezpieczeń, ponieważ oddziałuje na cała gospodarkę finansową ubezpieczyciela.

Analiza przedmiotowego zagadnienia wymaga jego oceny w szerszym kontekście istoty umowy ubezpieczenia na życie z ubezpieczeniowym funduszem kapitałowym oraz umowy ubezpieczenia na życie, w szczególności świadczeń wynikających z ww. umów. Ponadto w związku z pojawiającą się w orzecznictwie kwestią stosowania przepisów o bezpodstawnym wzbogaceniu do roszczenia o wypłatę całości lub części niewypłaconego świadczenia wykupu zasadne jest również przeprowadzenie w niniejszym artykule analizy w tym zakresie w związku z implikacja w zakresie przedawnienia roszczeń.

\section{Regulacje prawne dotyczące umowy ubezpieczenia na życie z ubezpieczeniowym funduszem kapitałowym}

Umowa ubezpieczenia na życie z ubezpieczeniowym funduszem kapitałowym charakteryzuje się tym, że zawiera ona zarówno elementy o charakterze ochronnym jak i elementy oszczędnościowo -inwestycyjne. Element ubezpieczeniowy tego rodzaju umowy polega na tym, że ubezpieczyciel zobowiązuje się do wypłaty świadczeń w razie zajścia przewidzianego w umowie wypadku (śmierci ubezpieczonego lub dożycia przez niego określonego wieku) a funkcja oszczędnościowo-inwestycyjna realizowana jest przede wszystkim poprzez obligatoryjne inwestowanie środków w ramach ubezpieczeniowych funduszy kapitałowych, co ma wpływ na wysokość wszystkich świadczeń wynikających z tej umowy.

Umowa ubezpieczenia na życie z ubezpieczeniowym funduszem kapitałowym funkcjonuje w Polsce od kilkudziesięciu lat, pierwsze tego typu umowy pojawiły się w połowie lat 90 -tych. W ww. okresie regulacja prawna tej umowy podlegała zmianom, pierwszym aktem prawnym ją regulującym była ustawa z dnia 28 lipca 1990 r. o działalności ubezpieczeniowej, następnie ustawa z dnia 22 maja 2003 r. o działalności ubezpieczeniowej a obecnie obowiązującym aktem prawnym jest ustawa z 11 września 2015 r. o działalności ubezpieczeniowej i reasekuracyjnej. W tym okresie umowa ubezpieczenia na życie z ubezpieczeniowym funduszem kapitałowym również uległa przeobrażeniom - między innymi pojawiły się umowy o przeważającym charakterze oszczędnościowo-inwestycyjnym. Ustawodawca ani w poprzednio obowiązujących ustawach ani w ustawie o działalności ubezpieczeniowej i reasekuracyjnej nie wprowadził kompleksowej regulacji tego rodzaju umowy, w szczególności nie wskazał progów minimalnych sum ubezpieczenia czy podziału składki na część ubezpieczeniową i inwestycyjna, pozostawiając w tym zakresie swobodę stronom umowy. Taki stan rzeczy jest też akceptowany przez regulatora i nigdy nie spotkał się z jego zastrzeżeniami. W obecnie obowiązującej ustawie o działalności ubezpieczeniowej i reasekuracyjnej ustawodawca rozbudował regulację dotyczącą obowiązków informacyjnych zakładu ubezpieczeń w umowie ubezpieczenia na życie z ubezpieczeniowym funduszem kapitałowym, ale przepisy te nie zawierają definicji tej umowy. Ze względu na ubezpieczeniowo - inwestycyjny/ oszczędnościowy charakter tych umów, stosunek zobowiązaniowy, których źródło stanowi ta umowa, jest regulowany zarówno przez przepisy kodeksu cywilnego jak i ustawy o działalności ubezpieczeniowej i reasekuracyjnej.

Definicja umowy ubezpieczenia zawarta w art. 805 k.c. określa, że przez umowę ubezpieczenia ubezpieczyciel zobowiązuje się, w zakresie działalności swego przedsiębiorstwa, spełnić 
określone świadczenie w razie zajścia przewidzianego w umowie wypadku, a ubezpieczający zobowiązuje się zapłacić składkę. Definicja ta ma charakter generalny i nie uwzględnia szczególnych rozwiązań prawnych występujących w poszczególnych różnorodnych umowach ubezpieczenia, w tym między innymi w umowie ubezpieczenia na życie z ubezpieczeniowym funduszem kapitałowym. Kodeks cywilny zawiera przepisy ogólne dotyczące wszystkich umów ubezpieczenia oraz szczególne regulacje dotyczące umów ubezpieczeń majątkowych i osobowych (ubezpieczenia na życie i ubezpieczenia następstw nieszczęśliwych wypadków). Regulacje dotyczacce wprost umowy ubezpieczenia na życie z ubezpieczeniowym funduszem kapitałowym zostały zawarte w ustawie o działalności ubezpieczeniowej i reasekuracyjnej (art. 21, 22, 23, 26). Dotyczą one przede wszystkim inwestycyjnych (kapitałowych) elementów umowy ubezpieczenia na życie z ubezpieczeniowym funduszem kapitałowym i wprowadzaja pewne dodatkowe lub odmienne uregulowania odnoszące się do tej umowy. ${ }^{1}$

Ustawa o działalności ubezpieczeniowej i reasekuracyjnej zawiera zarówno regulacje o charakterze administracyjnoprawnym dotyczące szeroko rozumianej działalności ubezpieczeniowej jak i cywilnoprawnym odnoszące się do elementów stosunku zobowiązaniowego. Ustawodawca zawarł w tej ustawie przepisy dotyczące wprost określonych rodzajów ubezpieczeń, w szczególności ubezpieczeń na życie. Niektóre z nich odnoszą się do ubezpieczeń, o których mowa w dziale I załącznika do ustawy (ubezpieczenia na życie) (art. 20 ustawy), inne dotyczą ubezpieczeń, o których mowa w dziale I w grupie 3 załącznika do ustawy (art. 21, 24 i 26 ustawy) lub wyłącznie umowy ubezpieczenia na życie z ubezpieczeniowym funduszem kapitałowym (art. 22 i 23 ustawy). Ze względu na to, że ustawa o działalności ubezpieczeniowej klasyfikuje umowy ubezpieczenia na życie z ubezpieczeniowym funduszem kapitałowym do Działu I załącznika do ustawy (ubezpieczenia na życie] przepisy odnoszące się do ubezpieczeń na życie będą miały zastosowanie bezpośrednio do umowy ubezpieczenia na życie z ubezpieczeniowym funduszem kapitałowym.

\section{Cechy charakterystyczne umowy ubezpieczenia na życie $z$ ubezpieczeniowym funduszem kapitałowym}

W obrocie, w ramach ogólnej konstrukcji umowy ubezpieczenia na życie z ubezpieczeniowym funduszem kapitałowym, funkcjonują umowy, które różnią się pomiędzy sobą niektórymi elementami. W ofercie ubezpieczycieli znajduje się szeroka gama umów ubezpieczenia na życie z ubezpieczeniowym funduszem kapitałowym, które różnią się między innymi takimi aspektami jak: relacja pomiędzy elementem ochronnym i inwestycyjnym, liczba ubezpieczeniowych funduszy kapitałowych, poprzez które inwestowane są wpłacane składki (umowy jednofunduszowe lub wielofunduszowe] czy rodzaj aktywów, w które inwestowane są środki. Różnorodność ta wynika ze swobody, którą ustawodawca pozostawił stronom umowy nie wprowadzając szczegółowych regulacji. Analiza historyczna pokazuje, że ustawodawca stopniowo rozbudowywał wymogi informacyjne, natomiast nie dokonywał regulacji tej umowy w zakresie np. proporcji między elementami ubezpieczeniowymi i oszczędnościowo-inwestycyjnymi. W obrocie prawnym występują umowy

1. Podobnie kwestia ta była uregulowana w poprzednio obowiązującej ustawie o działalności ubezpieczeniowej. Uregulowania „specjalne” dotyczące umowy ubezpieczenia na życie z ubezpieczeniowym funduszem kapitałowym znajdowały się w art. 13 tej ustawy. 
o przeważającym charakterze ochronnym, w których składka wpłacana przez ubezpieczającego jedynie w niewielkiej proporcji lokowana jest w ubezpieczeniowych funduszach kapitałowych. Ubezpieczyciele mają w swojej ofercie również umowy, w których relacja pomiędzy funkcją ochronną i oszczędnościowo-inwestycyjną jest zbilansowana i w których składka w porównywalnych częściach jest przeznaczana na pokrycie kosztów ochrony i inwestycje. W obrocie występują również umowy, w których przeważa funkcja oszczędnościowo-inwestycyjna, w związku z czym ich podstawowym celem jest inwestowanie środków finansowych pochodzących ze składek, a część ochronna jest relatywnie niewielka. W tego rodzaju umowach składka z reguły w całości inwestowana jest w ramach ubezpieczeniowych funduszy kapitałowych.

Nie budzi jednak wątpliwości, że każda taka umowa łączy ze sobą zarówno elementy ochronne jak i elementy oszczędnościowo-inwestycyjne, tworząc tym samym stosunek prawny o charakterze ochronno-inwestycyjnym/oszczędnościowym. Ochrona ubezpieczeniowa w tego rodzaju umowie wyraża się tak jak w klasycznej umowie ubezpieczenia w zobowiązaniu ubezpieczyciela do wypłaty świadczenia w razie zajścia przewidzianego w umowie wypadku, w tym przypadku zgonu ubezpieczonego lub dożycia przez niego określonego wieku (art. 23 ust. 1 pkt 2 ustawy o działalności ubezpieczeniowej i reasekuracyjnej]. Natomiast funkcja inwestycyjna/oszczędnościowa, która jest immamentna dla tej umowy realizowana jest poprzez lokowanie wpłaconych przez ubezpieczającego składek (ich określonej w umowie części) w ramach ubezpieczeniowych funduszy kapitałowych, a także w prawie ubezpieczającego do uzyskania szczególnego rodzaju świadczenia - wartości wykupu. Świadczenie to nie jest wypłacane jak świadczenie z przewidziane w art. 805 k.c. w związku z wystapieniem wypadku ubezpieczeniowego, ale co do zasady na wniosek ubezpieczającego, a jego wysokość jest pochodną wartości środków zgromadzonych na rachunku umowy ubezpieczenia. ${ }^{2}$

Immamentnym elementem tego rodzaju umowy, wynikającym z obowiązujących przepisów prawa, jest ubezpieczeniowy fundusz kapitałowy, w który lokowane są środki pochodzące ze składek ubezpieczających. Zgodnie z art. 3 ust. 1 pkt 50 ustawy o działalności ubezpieczeniowej i reasekuracyjnej jest to wydzielony fundusz aktywów stanowiący rezerwę tworzoną ze składek ubezpieczeniowych, inwestowany w sposób określony w umowie ubezpieczenia. W rezultacie w umowie ubezpieczenia na życie z ubezpieczeniowym funduszem kapitałowym wysokość świadczeń z reguły jest pochodną wartości środków ubezpieczającego zgromadzonych w ubezpieczeniowych funduszach kapitałowych. Dotyczy to również świadczeń o charakterze ochronnym, gdyż w przypadku tych świadczeń umowa może przewidywać wypłatę sumy ubezpieczenia w określonej z góry wysokości lub wypłatę wyższej z dwóch kwot - sumy ubezpieczenia lub wartości rachunku ${ }^{3}$. W związku z powyższym cechą charakterystyczną tego rodzaju umów, określona przez ustawodawcę, jest również to, że są to umowy na ryzyko ubezpieczającego.

W każdej umowie ubezpieczenia na życie z ubezpieczeniowym funduszem kapitałowym występują specyficzne świadczenia, wypłacane na wniosek ubezpieczającego - wykup częściowy i wykup całkowity (por. art. 23 ust. 1 pkt 2 ustawy o działalności ubezpieczeniowej i reasekuracyjnej,

2. Świadczenie wykupu jest wypłacane również w innych przypadkach, np. w przypadku braku zapłaty składki obowiązkowej lub w przypadku wypowiedzenia umowy.

3. Na rynku występują też w tym przypadku inne warianty, jednakże co do zasady wynik inwestycyjny ma wpływ na ustalenie wysokości świadczenia o charakterze ochronnym. 
w którym to przepisie świadczenia te zostały wprost wymienione]. Wykup częściowy pozwala wypłacić część środków zgromadzonych w ubezpieczeniowych funduszach kapitałowych a wykup całkowity stanowi świadczenie wypłacane w związku z rozwiązaniem umowy przez ubezpieczajacego. Zasady ustalania wartości ww. świadczeń są określone przez strony w umowie ubezpieczenia na życie z ubezpieczeniowym funduszem kapitałowym. ${ }^{4}$

W literaturze przedmiotu przeważa poglad, że umowa ubezpieczenia na życie z ubezpieczeniowym funduszem kapitałowym jest umową mieszana. ${ }^{5} \mathrm{~W}$ literaturze prezentowany jest również pogląd, że umowa ubezpieczenia na życie z ubezpieczeniowym funduszem kapitałowym jest rodzajem umowy ubezpieczenia. ${ }^{6}$ Kwestia charakteru prawnego umowy ubezpieczenia na życie z ubezpieczeniowym funduszem kapitałowym była również przedmiotem orzeczeń zarówno sadów powszechnych jak i Sądu Najwyższego? W orzecznictwie SN reprezentowany jest pogląd, że umowa ubezpieczenia na życie z ubezpieczeniowym funduszem kapitałowym jest umowa mieszana z elementami klasycznego modelu umowy ubezpieczenia na życie oraz postanowieniami charakterystycznymi dla umów, których celem jest inwestowanie kapitału. Pogląd ten jest również prezentowany w orzecznictwie sądów powszechnych. ${ }^{8}$

Należy wskazać, że SN uznał, że umowa ubezpieczenia na życie z ubezpieczeniowym funduszem kapitałowym pozostaje w zgodzie z art. 805 k.c., jak i art. 3 ust. 2 ustawy z dnia 22 maja 2003 r. o działalności ubezpieczeniowej, a tym samym nie można stwierdzić nieważności tej umowy na podstawie art. 58 § 1 k.c. Brak jest też przesłanek do uznania jej sprzeczności z zasadami współżycia społecznego lub z ustalonymi zwyczajami. ${ }^{9}$

Do problematyki ubezpieczeń na życie z ubezpieczeniowym funduszem kapitałowym odnosił się również TSUE. W orzecznictwie TSUE ${ }^{10}$ reprezentowany jest pogląd, że umowy zwane „unit linked”, „wyrażone w jednostkach przeliczeniowych” lub „związane z funduszami inwestycyjnymi" sa powszechne w prawie ubezpieczeń. Ponadto prawodawca unijny uznał, że ten typ umowy należy do grupy ubezpieczeń na życie, tak jak to wyraźnie wynika z pkt III załącznika I do dyrektywy 2002/83/WE dotyczącej ubezpieczeń na życie w związku z art. 2 pkt 1 lit. a) tej dyrektywy. ${ }^{11}$ Podkreślić należy, że ubezpieczenia związane z funduszami inwestycyjnymi były uważane za należące do grupy ubezpieczeń na życie już na gruncie dyrektywy 79/26? (zgodnie z art. 1

4. M. Szczepańska, Wypłata wartości wykupu w umowie ubezpieczenia na życie z ubezpieczeniowym funduszem kapitałowym - charakter prawny świadczenia, Wiadomości Ubezpieczeniowe 3/2015, s. 9 ?.

5. M. Romanowski, Umowa ubezpieczenia na życie z ubezpieczeniowym funduszem kapitałowym w świetle przepisów Kodeksu cywilnego i projektowanych w tym zakresie zmian, Wiadomości Ubezpieczeniowe nr specjalny 3/2013 s. 11., W. Kamieński, Glosa do wyroku Sqdu Apelacyjnego w Warszawie z dnia 14 maja 2010 r. dotyczqcego wysokości opłaty likwidacyjnej, Rozprawy Ubezpieczeniowe 13 [2/2012], s. 166.

6. B. Mrozowska-Bartkiewicz, Charakter prawny ubezpieczenia na życie z ubezpieczeniowym funduszem kapitałowym, PA 2015, nr 2, s. 25.

7. Wyrok SN z dnia 18 grudnia 2013 r. (sygn. akt. I CSK 149/13), wyrok SO w Krakowie z 18 września 2015 r. (sygn. akt II Ca 1140/15), wyrok Sądu Rejonowego dla Warszawy - Mokotowa z 4 kwietnia 2014 r. (sygn. akt. II C 869/14].

8. V Ca 3049/14 - uzasadnienie Sąd Okręgowy w Warszawie z 2015-09-01.

9. Wyrok SN z 22 listopada 2017 r. (sygn. akt IV CSK 61/17)

10. Wyrok TSUE z 1 marca 2012 r. w sprawie C-166/11 Ángel Lorenzo González Alonso przeciwko Nationale Nederlanden Vida Cia De Seguros y Reaseguros SAE

11. Dyrektywa 2002/83/WE Parlamentu Europejskiego i Rady z dnia 5 listopada 2002 r. dotycząca ubezpieczeń na życie (Dz.U. L 345, s. 1) 
pkt 1 lit. a) dyrektywy 79/267, a także pkt III załącznika do niej). ${ }^{12}$ Analogicznie kwestia ta jest regulowana przez obecnie obowiązująca dyrektywę Wypłacalność II (zgodnie z art. 2 ust. 3 pkt a lit. i oraz punkt III załącznika II do niej). ${ }^{13}$

Ponadto TSUE ${ }^{14}$ uznał również, że doradztwo finansowe dotyczące inwestowania kapitału udzielone w ramach pośrednictwa ubezpieczeniowego dotyczacego zawarcia umowy ubezpieczenia na życie z ubezpieczeniowym funduszem kapitałowym wchodzi w zakres stosowania dyrektywy 2002/92/WE Parlamentu Europejskiego i Rady z dnia 9 grudnia 2002 r. w sprawie pośrednictwa ubezpieczeniowego, a nie w zakres stosowania dyrektywy 2004/39/WE Parlamentu Europejskiego i Rady z dnia 21 kwietnia 2004 r. w sprawie rynków instrumentów finansowych zmieniającej dyrektywę Rady 85/611/EWG i 93/6/EWG i dyrektywę 2000/12/WE Parlamentu Europejskiego i Rady oraz uchylającej dyrektywę Rady 93/22/EWG. Przyjał on, że w zakresie pojęcia „umowy ubezpieczenia", o którym mowa w art. 2 pkt 3 dyrektywy 2002/92/WE mieści się umowa ubezpieczenia na życie z ubezpieczeniowym funduszem kapitałowym.

\section{Umowa ubezpieczenia na życie a umowa ubezpieczenia na życie z ubezpieczeniowym funduszem kapitałowym}

Należy przyjąć, że umowa ubezpieczenia z ubezpieczeniowym funduszem kapitałowym wywodzi się z konstrukcji ogólnej umowy ubezpieczenia. Umowa ubezpieczenia na życie z ubezpieczeniowym funduszem kapitałowym zawiera wszystkie elementy wskazane przez ustawodawcę w art. 805 k.c. charakteryzujące umowę ubezpieczenia tzn. przewiduje wypłatę świadczeń w razie zajścia wypadku oraz zobowiązanie ubezpieczającego do zapłaty składki ubezpieczeniowej. Stanowisko to potwierdził SN, który uznał, że umowy ubezpieczenia na życie z ubezpieczeniowym funduszem kapitałowym "genetycznie" oparte zostały na konstrukcji umowy ubezpieczenia, przewidując obok elementu zarządzania przez ubezpieczyciela kapitałem pochodzącym ze składek ubezpieczającego także typowe elementy wskazane w art. 805 k.c. jako essentialia negotii tej umowy. ${ }^{15}$ Unormowania regulujące ten rodzaj umowy, zawarte w ustawie o działalności ubezpieczeniowej oraz postanowienia ogólnych warunków ubezpieczenia określaja dodatkowe lub odmienne elementy tej umowy, nadając jej szczególny charakter (np. obligatoryjny element jakim jest ubezpieczeniowy fundusz kapitałowy, prawo ubezpieczającego do kształtowania indywidualnej polityki inwestycyjnej, umowa na ryzyko ubezpieczającego].

W umowie ubezpieczenia na życie z ubezpieczeniowym funduszem kapitałowym stronami umowy są ubezpieczyciel i ubezpieczający. Nie budzi wątpliwości, że ubezpieczyciel jest uprawniony do oferowania tego rodzaju umów na podstawie ustawy o działalności ubezpieczeniowej i reasekuracyjnej, która w załączniku do ustawy określa, że umowa ubezpieczenia z ubezpieczeniowym

12. Pierwsza dyrektywa Rady 79/267/EWG z dnia 5 marca 1979 r. w sprawie koordynacji przepisów ustawowych, wykonawczych i administracyjnych odnoszących się do podejmowania i prowadzenia działalności w dziedzinie bezpośrednich ubezpieczeń na życie (Dz.U. L 63, s. 1)

13. Dyrektywa Parlamentu Europejskiego i Rady 2009/138/WE z dnia 25 listopada 2009 r. w sprawie podejmowania i prowadzenia działalności ubezpieczeniowej i reasekuracyjnej (Wypłacalność II)

14. Wyrok TSUE z 31 maja 2018 r. w sprawie C-542/16 Länsförsäkringar Sak Försäkringsaktiebolag przeciwko Dödsboet efter Ingvar Mattsson

15. Wyrok SN z 22 listopada 2017 r. (sygn. akt IV CSK 61/17) 
funduszem kapitałowym stanowi jedną z grup Działu I (Ubezpieczenia na życie) według załącznika do ustawy o działalności ubezpieczeniowej i reasekuracyjnej, co oznacza, że zgodnie z ta ustawą są one klasyfikowane do ogólnej grupy ubezpieczeń na życie. W związku z powyższym w umowie ubezpieczenia z ubezpieczeniowym funduszem kapitałowym strony umowy są tożsame ze stronami umowy ubezpieczenia, w szczególności umowy ubezpieczenia na życie. Podmiotami analizowanej umowy innymi niż strony umowy mogą być ubezpieczony i uprawniony z umowy ubezpieczenia (uposażony), które to podmioty są charakterystyczne również dla klasycznych umów ubezpieczenia na życie.

Zarówno w przypadku umowy ubezpieczenia na życie, jak i umowy ubezpieczenia na życie z ubezpieczeniowym funduszem kapitałowym występuje tożsamy przedmiot ochrony ubezpieczeniowej - życie oraz rodzaje wypadków ubezpieczeniowych objętych ochroną ubezpieczeniową - śmierć albo dożycie określonego wieku. W aspekcie ochronnym umowy ubezpieczenia na życie z ubezpieczeniowym funduszem kapitałowym ochrona ubezpieczeniowa obejmuje konsekwencje zgonu ubezpieczonego lub dożycia przez niego określonego wieku.

W obu rodzajach umów przewidziano wypłatę określonych świadczeń w razie zajścia przewidzianego w umowie wypadku, którym może być śmierć ubezpieczonego lub dożycie przez niego określonego wieku. Zgodnie z art. 805 § 2 k.c. świadczenie ubezpieczyciela polega w szczególności na zapłacie przy ubezpieczeniu osobowym - umówionej sumy pieniężnej, renty lub innego świadczenia w razie zajścia przewidzianego w umowie wypadku w życiu osoby ubezpieczonej. Powyższe przepisy wskazuja, że ustawodawca nie wskazał zamkniętego katalogu świadczeń w ubezpieczeniach osobowych jak również nie sprecyzował w jaki sposób mają być one ustalane.

W art. 23 ust. 1 pkt 2 ustawy o działalności ubezpieczeniowej i reasekuracyjnej wskazano, że w umowie ubezpieczenia na życie, jeżeli jest związana z ubezpieczeniowym funduszem kapitałowym, o której mowa w dziale I w grupie 3 załącznika do ustawy, zakład ubezpieczeń określa: zasady ustalania wartości świadczeń z umowy ubezpieczenia z tytułu śmierci ubezpieczonego i dożycia ubezpieczonego do końca okresu ochrony ubezpieczeniowej, a także zasady ustalania wartości całkowitego i częściowego wykupu ubezpieczenia. Powyższe oznacza, że w każdej umowie ubezpieczenia na życie z ubezpieczeniowym funduszem kapitałowym wypłacane mogą być świadczenia z tytułu zgonu lub dożycia określonego wieku (może być przewidziane wyłączenie świadczenie z tytułu zgonu) oraz świadczenia w postaci wykupu częściowego i wykupu całkowitego, które sa wypłacane na wniosek ubezpieczającego. ${ }^{16}$ Na podstawie wzorców umownych funkcjonujących w obrocie należy przyjać, że świadczenia pieniężne (sumy pieniężne wypłacane w razie zgonu lub dożycia oraz świadczenia wykupu) charakterystyczne dla umowy ubezpieczenia na życie z ubezpieczeniowym funduszem kapitałowym występują również w umowach ubezpieczenia na życie. Wszystkie te świadczenia mają charakter pieniężny, inny może być jedynie sposób ustalania ich wysokości. Podkreślenia przy tym wymaga, że wartość wykupu jak jedno ze świadczeń z tytułu klasycznej umowy ubezpieczenia na życie zostało wprost wskazane przez ustawodawcę w regulacji zawartej w art. 20 ust. 1 pkt 3 oraz art. 17 ust. 1 pkt 4 ustawy o działalności ubezpieczeniowej i reasekuracyjnej. ${ }^{17}$

16. M. Szczepańska, Wypłata wartości wykupu w umowie ubezpieczenia na życie z ubezpieczeniowym funduszem kapitałowym - charakter prawny świadczenia, Wiadomości Ubezpieczeniowe 3/2015, s. 9 ?.

17. Wartość wykupu jako jedno ze świadczeń z tytułu klasycznej umowy ubezpieczenia na życie było również wprost wskazane w art. 13 ust. 1 pkt 3 poprzednio obowiązującej ustawy o działalności ubezpieczeniowej. 
W obu rodzajach umów sposób ustalania wysokości tych świadczeń ustawodawca pozostawił stronom umowy. W umowie ubezpieczenia na życie z ubezpieczeniowym funduszem kapitałowym wysokość ww. świadczeń co do zasady jest uzależniona od wyników inwestycyjnych osiaganych przez ubezpieczeniowe fundusze kapitałowe. Jednak obecnie nawet w klasycznych ubezpieczeniach na życie wysokość świadczenia z tytułu zgonu rzadko stanowi określoną kwotową wartość, niezmienna przez cały okres ubezpieczenia. Z reguły jej wysokość jest zwiększana poprzez zastosowanie mechanizmu indeksacji. Ponadto często ubezpieczyciele przewidują wypłatę dodatkowych świadczeń takich jak premie, rabaty lub udział w zyskach, które wpływają na wysokość świadczeń przysługujacych uprawnionym.

W ramach umowy ubezpieczenia na życie z ubezpieczeniowym funduszem kapitałowym ubezpieczający jest zobowiązany do zapłaty składki ubezpieczeniowej. W tego rodzaju umowie część składki przeznaczona jest na pokrycie ryzyka ubezpieczeniowego oraz koszty zakładu ubezpieczeń z tytułu prowadzenia działalności ubezpieczeniowej związanej z udzielaniem ochrony na wypadek ryzyka wystapienia skutków zdarzeń losowych a pozostała część składki jest inwestowana w ramach ubezpieczeniowych funduszy kapitałowych. W klasycznych umowach ubezpieczenia na życie składka może być wyłącznie przeznaczana na pokrycie kosztów ochrony ubezpieczeniowej oraz działalności ubezpieczeniowej, ale co do zasady środki z niej pochodzące są również inwestowane przez ubezpieczyciela i buduja w zależności od rodzaju umowy w mniejszym lub większym stopniu oszczędnościowy element umowy, który przekłada się również na wartość wykupu. Wynika to z istoty umowy ubezpieczenia na życie, która ma z reguły charakter długoterminowy (nota bene podobnie długoterminowy charakter moga mieć umowy ubezpieczenia na życie z ubezpieczeniowym funduszem kapitałowym ${ }^{18}$ ] oraz z ustalenia wysokości składki w tej samej wysokości przez cały okres trwania umowy, pomimo zwiększającego się ryzyka zgonu ubezpieczonego wraz z jego starzeniem się.

Powyżej przedstawiona analiza umowy ubezpieczenia na życie z ubezpieczeniowym funduszem kapitałowym i umowy ubezpieczenia na życie wskazuje, że umowy te wykazuja istotne podobieństwa, w szczególności świadczenia o charakterze ubezpieczeniowym z tytułu zajścia wypadku ubezpieczeniowego oraz świadczenie wartości wykupu (częściowego i całkowitego) występują zarówno w umowie ubezpieczenia na życie i w umowie ubezpieczenia na życie z ubezpieczeniowym funduszem kapitałowym. Należy wskazać, że charakter prawny tych świadczeń jest taki sam w obu rodzajach umów. Różnica pomiędzy tymi świadczenia może dotyczyć jedynie sposobu ustalania ich wysokości, co dopuszcza ustawodawca, natomiast nie jest to cecha relewantna uzasadniająca odmienne traktowanie tych świadczeń.

18. W literaturze przedmiotu reprezentowane jest stanowisko, że umowy ubezpieczenia na życie z ubezpieczeniowym funduszem kapitałowy charakteryzują się bardziej otwartą formułą okresu trwania ubezpieczenia, por. M. Wiśniewski, Wartość wykupu polis życiowych z Ubezpieczeniowym Funduszem Kapitałowym, Wiadomości Ubezpieczeniowe 2/2012, s. 29. 


\section{Zastosowanie przepisów k.c. o umowie ubezpieczenia, w szczególności przepisów o przedawnieniu roszczeń z umowy ubezpieczenia do umowy ubezpieczenia na życie z ubezpieczeniowym funduszem kapitałowym}

Jak wskazano powyżej umowa ubezpieczenia na życie z ubezpieczeniowym funduszem kapitałowym łączy elementy ubezpieczeniowe i oszczędnościowo-inwestycyjne. Ustawodawca jak i strony umowy kształtując jej treść korzystali z rozwiązań charakterystycznych dla umowy ubezpieczenia, w szczególności umowy ubezpieczenia na życie. W związku z powyższym w konstrukcji umowy zostały zawarte elementy klasycznej umowy ubezpieczenia na życie oraz dodatkowo inne elementy o charakterze inwestycyjno-oszczędnościowym, które nadajajej specyficzny charakter. ${ }^{19}$ Ze względu na taki charakter umowy ubezpieczenia na życie z ubezpieczeniowym funduszem kapitałowym będa miały w stosunku do niej zastosowanie zarówno przepisy k.c. jak i ustawy o działalności ubezpieczeniowej i reasekuracyjnej.

Z zagadnieniem umowy ubezpieczenia na życie z ubezpieczeniowym funduszem kapitałowym wiąże się problematyka zastosowania do niej przepisów dotyczących umowy ubezpieczenia zawartych w k.c. Nie budzi wątpliwości, że będą miały zastosowanie do niej ogólne przepisy dotyczące czynności prawnych, zobowiązań (w szczególności umów) ze względu na to, że regulacja umowy ubezpieczenia w k.c. ma charakter fragmentaryczny i dotyczy tylko niektórych aspektów stosunku ubezpieczenia.

W przypadku umowy ubezpieczenia na życie z ubezpieczeniowym funduszem kapitałowym należy uznać, że jest to, jak wykazano, umowa zbliżona konstrukcyjnie do umowy ubezpieczenia, przede wszystkim do umowy ubezpieczenia na życie, w szczególności zaś podobny lub wręcz tożsamy jest charakter świadczeń wynikających z obu tych umów. Ponadto sens ekonomiczny tych obu rodzajów umów jest co do zasady bardzo podobny, a w niektórych przypadkach tożsamy. ${ }^{20} Z$ uwagi na powyższe podobieństwo pomiędzy ww. umowami uzasadnione jest stosowanie przepisów k.c. regulujących umowę ubezpieczenia do umowy ubezpieczenia na życie z ubezpieczeniowym funduszem kapitałowym. W doktrynie przyjmuje się, że nawet w przypadku umów nienazwanych, gdy pomiędzy daną umową a odpowiednim typem umowy istnieje podobieństwo, uzasadnione jest stosowanie tych przepisów per analogiam. W przypadku umów mieszanych stosownie do użytej jednej z trzech metod - metody absorpcji, metody kombinowanej oraz analogii (enumeracyjnej] mogą być stosowane różne zasady. Można stosować do całej umowy przepisy wybranego normatywnego typu umowy. W przypadku, gdy w konkretnej umowie można wyróżnić kilka równorzędnych elementów lub świadczeń, które moga zostać przyporządkowane różnym normatywnym typom umów, do różnych części umowy zastosowanie maja przepisy różnych normatywnych umów (lub tych samych jeżeli te równorzędne elementy i świadczenia są charakterystyczne dla tego samego typu umowy nazwanej]. Gdy w danej umowie nie można w ogóle wyróżnić elementów (świadczeń) dających się wprost przyporządkować normatywnym typom umowy, ale te elementy (świadczenia) cechuje odpowiedni stopień podobieństwa do jakiegoś normatywnego typu umowy, wtedy możliwe jest stosowania przepisów dotyczących tego typu per analogiam. ${ }^{21}$

19. J. Ignaczewski, Umowy nienazwane, Warszawa 2004, s. 4.

20. M. Orlicki w: Prawo zobowiązań - umowy nienazwane (red. W. J. Katner) Tom 9, Warszawa 2015, s. 778.

21. S. Włodyka w: S. Włodyka (red.), Prawo umów handlowych, Tom 5, Warszawa 2006, s. 48 - 49 
Generalnie o możliwości zastosowania do umowy mieszanej określonych przepisów dotyczących normatywnego typu umowy decyduje podobieństwo umowy mieszanej do danego normatywnego typu umowy, w szczególności zaś podobieństwo elementów i świadczeń charakterystycznych.

W doktrynie ani w orzecznictwie nie budzi wattpliwości stosowanie do całości umowy ubezpieczenia na życie z ubezpieczeniowym funduszem kapitałowym nie tylko przepisów k.c. dotyczących ubezpieczeń osobowych (art. 829 - 834) ale również przepisów ogólnych k.c. regulujących umowę ubezpieczenia (np. art. 806, 807, 812). Stąd też nie znajdowałoby uzasadnienia wyłacczenie zastosowania do całości umowy ubezpieczenia na życie z ubezpieczeniowym funduszem kapitałowym przepisu art. 819 § 1 k.c. określającego termin przedawnienia roszczeń. Uznać należy, że w takim zakresie, w jakim prawa i obowiązki stron zostały uregulowane w kodeksie cywilnym, przepisy tej ustawy wprost znajdują zastosowanie do umowy ubezpieczenia na życie z ubezpieczeniowym funduszem kapitałowym. Przepisy ustawy o działalności ubezpieczeniowej i reasekuracyjnej znajduja zaś zastosowanie do umowy ubezpieczenia na życie z ubezpieczeniowym funduszem kapitałowym w kwestiach dodatkowych regulowanych przez tę ustawę oraz ewentualnie tam, gdzie wprowadzaja one odmienności w stosunku do regulacji kodeksowych (np. przepis o odstapieniu od umowy - art. 26 ustawy o działalności ubezpieczeniowej i reasekuracyjnej].

Jak zostało przedstawione powyżej świadczeniami głównymi ubezpieczyciela w umowie ubezpieczenia na życie z ubezpieczeniowym funduszem kapitałowym o charakterze pieniężnym są świadczenia z tytułu zajścia ryzyk ubezpieczeniowych (śmierć ubezpieczonego lub dożycie przez niego określonego wieku) oraz świadczenia wykupu (częściowego i całkowitego) a głównym świadczeniem ubezpieczającego jest zapłata składki ubezpieczeniowej. Analogiczne świadczenia występują w klasycznej umowie ubezpieczenia na życie. Nie budzi wątpliwości, że w odniesieniu do składki ubezpieczeniowej płaconej przez ubezpieczającego w umowie ubezpieczenia na życie z ubezpieczeniowym funduszem kapitałowym będą miały wprost zastosowanie przepisy k.c. (art. $813 \S 1$ k.c., art. 814 k.c.) stosowane w odniesieniu do wszystkich umów ubezpieczenia. Dotyczy to również terminu przedawnienia roszczenia ubezpieczyciela o zapłatę składki określonego w art. 819 § 1 k.c. Znamiennym jest, że ustawodawca nie przewidział, że ubezpieczający obok składki ubezpieczeniowej jest zobowiązany do zapłaty innego świadczenie przeznaczonego wyłącznie na inwestycje, a wręcz przeciwnie - ubezpieczający wpłaca tylko i wyłacznie składkę. Gdyby ustawodawca chciał wyróżnić (oddzielić) część inwestycyjną i poddać ją innemu reżimowi prawnemu, to wymagałoby innej regulacji - mimo nowelizacji k.c. i uchwalenia nowej ustawy o działalności ubezpieczeniowej i reasekuracyjnej takiej zmiany nie wprowadzono. Analogicznie w odniesieniu do świadczeń o charakterze ubezpieczeniowym jak i świadczeń wykupu występujących w umowach ubezpieczenia na życie jak i umowach ubezpieczenia na życie z ubezpieczeniowym funduszem kapitałowym powinny mieć zastosowanie te same przepisy k.c., w tym w szczególności art. 819 § 1 k.c. Nie budzi watpliwości, że również w przypadku tych świadczeń sytuacja prawna stron umowy powinna być analogiczna jak w przypadku składki. Nie ma bowiem merytorycznych podstaw do różnicowania sytuacji prawnej uprawnionych w umowie ubezpieczenia na życie i w umowie ubezpieczenia na życie z ubezpieczeniowym funduszem kapitałowym w zakresie terminu przedawnienia roszczeń, ponieważ w tym aspekcie umowy wykazują istotne podobieństwa uzasadniające traktowanie ich w taki sam sposób. 
Przyjęcie odmiennych koncepcji prowadziłoby do kuriozalnych i niemożliwych do zaakceptowania skutków. Przyjęcie modelu zastosowania innego terminu przedawnienia do świadczeń o charakterze ochronnym a innego do świadczeń wykupu budzi poważne wattpliwości. Przede wszystkim w jednej umowie funkcjonowałyby dwa terminy przedawnienia roszczeń w stosunku do świadczeń wypłacanych przez ubezpieczyciela, które - z punktu widzenia zasad ustalania ich wysokości - mają tożsamy charakter. W praktyce mogłoby to doprowadzić do sytuacji, gdy dla osób uprawnionych korzystniejszym rozwiązanie będzie realizacja świadczenia wykupu na dzień przed dożyciem wieku wskazanego w umowie (oba te świadczenia mogą być wówczas w tej samej wysokości] niż wypłata świadczenia z tytułu dożycia ze względu na dłuższy okres przedawnienia roszczeń. W przypadku przyjęcia modelu zastosowania dłuższego terminu przedawnienia roszczeń do wszystkich świadczeń z umowy ubezpieczenia na życie z ubezpieczeniowym funduszem kapitałowym pojawiłaby się nieuzasadniona konkurencja pomiędzy tymi umowami a umowami ubezpieczenia na życie, w szczególności, jeżeli umowa ubezpieczenia na życie z ubezpieczeniowym funduszem kapitałowym miałaby w przeważającej mierze charakter ochronny. Powyższe oznaczałoby również nieuzasadnione i niezgodne z prawem wydłużenie terminu przedawnienia roszczenia o zapłatę składki.

W konsekwencji do umowy ubezpieczenia na życie z ubezpieczeniowym funduszem kapitałowym należy stosować przepis dotyczący terminów przedawnienia roszczeń z umowy ubezpieczenia tzn. art. 819 § 1 k.c., co dotyczy również roszczenia o zapłatę części wartości wykupu niewypłaconej w związku z postanowieniami o.w.u. uznanymi następnie za abuzywne. W przypadku tej umowy ze względu na jej konstrukcję, a w szczególności charakter świadczeń pieniężnych stron umowy powyższy przepis o przedawnieniu roszczeń powinien mieć zastosowanie wprost. Przepis ten bowiem ma charakter generalny i odpowiada zarówno istocie umowy ubezpieczenia jak i umowy ubezpieczenia na życie z ubezpieczeniowym funduszem kapitałowym. Przedmiotowe stanowisko znajduje uzasadnienie również w orzecznictwie SN, który stwierdził, że termin przedawnienia roszczeń z tytułu umowy sprzedaży znajdzie zastosowanie także do umów dostawy ze względu na podobieństwo zachodzące między umową dostawy a umową sprzedaży (wyrok SN z 9 lutego 2005 r., II CK 423/04, Biul. SN z 2005 r., nr 7, poz.12]. W związku z powyższym należy uznać, że podobieństwo umów, w szczególności świadczeń stanowi zasadne kryterium stosowania tego samego terminu przedawnienia roszczeń.

Należy wskazać, że w przypadku przyjęcia koncepcji, że umowa ubezpieczenia na życie z ubezpieczeniowym funduszem kapitałowym jest rodzajem umowy ubezpieczenia nie budzi wạtpliwości, że zastosowanie będzie miał art. 819 k.c.

\section{Brak podstaw dla stosowania przepisów o bezpodstawnym wzbogaceniu do roszczenia o wypłatę świadczenia wartości wykupu}

W związku z pojawiającym się w orzecznictwie zagadnieniem stosowania przepisów o bezpodstawnym wzbogaceniu do roszczenia o wypłatę całości lub części niewypłaconego świadczenia wykupu zasadne jest przeprowadzenie analizy w tym zakresie w związku z implikacją w zakresie przedawnienia roszczeń. Kluczową kwestią dla rozstrzygnięcia zasadności stosowania przepisów o bezpodstawnym wzbogaceniu jest ustalenie, czy roszczenie o wykup ma podstawę prawną w przepisach o bezpodstawnym wzbogaceniu (nienależnym świadczeniu) czy w przepisach 
dotyczacych zawartej umowy. Świadczenie wykupu (zarówno częściowego jak i całkowitego) jak wskazano powyżej jest świadczeniem z umowy ubezpieczenia na życie z ubezpieczeniowym funduszem kapitałowym. Kwestia ta nie budzi wạtpliwości zarówno w świetle przepisów ustawy o działalności ubezpieczeniowej i reasekuracyjnej (art. 23 ust. 1 pkt 2), jak i postanowień o.w.u. funkcjonujących w obrocie.

Nawet w przypadku „potrącania”22 przez ubezpieczyciela ze świadczenia wykupu opłaty likwidacyjnej, nie stanowi ona odrębnego świadczenia ubezpieczającego. W przypadku gdy jest ona stosowana przez ubezpieczycieli stanowi ona jedynie element ustalenia wysokości świadczenia ubezpieczeniowego jakim jest wykup. Jedynym świadczeniem, jakie spełnia ubezpieczający na rzecz ubezpieczyciela pozostaje zapłata składki. Zakład ubezpieczeń nie wzbogaca się więc kwotą opłaty likwidacyjnej. W związku z powyższym uprawnieni nie mogą mieć względem ubezpieczyciela roszczenia o zwrot z tytułu nienależnego świadczenia. Świadczenie wykupu jest samodzielnym świadczeniem przysługującym z umowy ubezpieczenia. W przypadku uznania postanowienia o ustaleniu kwoty wykupu z uwzględnieniem opłaty likwidacyjnej za bezskuteczne to uprawnionym nadal przysługuje roszczenie o zapłatę świadczenia wykupu. Nie budzi zatem wạtpliwości, że jest to roszczenie z umowy ubezpieczenia na życie z ubezpieczeniowym funduszem kapitałowym.

W przypadku występujących w ofercie ubezpieczycieli umów, w których wartość świadczenia wykupu jest ustalana jako procent rachunku ubezpieczenia, czyli wariant, w którym nie występuje opłata likwidacyjna, również nie mamy do czynienia z roszczeniem o zwrot nienależnego świadczenia, na co wskazuje ww. argumentacja, przede wszystkim nie budzącą wạtpliwości kwestia że jedynym świadczeniem ubezpieczającego jest zapłata składki.

Nie jest dopuszczalne powoływanie się na bezpodstawne wzbogacenie w stosunkach prawnych, których źródłem jest umowa. Należy podkreślić, że roszczenie z bezpodstawnego wzbogacenia ma charakter subsydiarny w stosunku do roszczeń kontraktowych i nie może występować wewnatrz stosunków umownych. W przypadku, gdy stronie umowy przysługuje wierzytelność umowna, może ona dochodzić tylko takiej wierzytelności. W przeciwnym wypadku nieracjonalnym ze strony ustawodawcy byłoby szczegółowe regulowanie przez prawodawcę poszczególnych typów zobowiązań, z uwzględnieniem szczególnych terminów przedawnienia wynikających z nich roszczeń. Ponadto przepisy o bezpodstawnym wzbogaceniu nie mogą służyć do konstruowania odpowiedzialności dłużnika wobec wierzyciela, która miałaby zastępować odpowiedzialność z tytułu niewykonania lub nienależytego wykonania umowy. Przedmiotowe stanowisko jest powszechnie reprezentowane w orzecznictwie (zob. np. wyroki Sadu Najwyższego z 19 lutego 2002 r., IV CKN 786/00; z 21 grudnia 2005 r., IV CK 305/05 i z 3 grudnia 2004 r., IV CK 347/04). Nie budzi watpliwości, że przepisy o bezpodstawnym wzbogaceniu nie moga być stosowane po upływie przedawnienia roszczenia kontraktowego dla zniweczenia skutków upływu terminu przedawnienia (zob. np. wyrok Sądu Najwyższego z 18 grudnia 1968 r., I CR 448/68).

22. Podkreślić należy, że nie jest to potrącenie w rozumieniu przepisów k.c. ani też nie ma tutaj mowy o potrąceniu umownym. 


\section{Podsumowanie}

Ze względu na podobieństwo pomiędzy umową ubezpieczenia, w szczególności umową ubezpieczenia na życie, a umową ubezpieczenia na życie z ubezpieczeniowym funduszem kapitałowym uzasadnione jest stosowanie przepisów dotyczących umowy ubezpieczenia do umowy ubezpieczenia na życie z ubezpieczeniowym funduszem kapitałowym, a w szczególności przepisu dotyczącego terminów przedawnienia roszczeń z umowy ubezpieczenia tzn. art. 819 § 1 k.c., co dotyczy również roszczenia o świadczenie wykupu, w tym roszczenia o zapłatę części wartości wykupu niewypłaconej w związku z postanowieniami o.w.u. uznanymi następnie za abuzywne.

\section{Wykaz źródeł}

J. Ignaczewski, Umowy nienazwane, Warszawa 2004

W. Kamieński, Glosa do wyroku Sqdu Apelacyjnego w Warszawie z dnia 14 maja 2010 r. dotyczqcego wysokości opłaty likwidacyjnej, Rozprawy Ubezpieczeniowe 13 (2/2012]

B. Mrozowska-Bartkiewicz, Charakter prawny ubezpieczenia na życie z ubezpieczeniowym funduszem kapitałowym, PA 2015, nr 2

M. Orlicki w: Prawo zobowiqzań - umowy nienazwane (red. W. J. Katner) Tom 9, Warszawa 2015

M. Romanowski, Umowa ubezpieczenia na życie z ubezpieczeniowym funduszem kapitałowym w świetle przepisów Kodeksu cywilnego i projektowanych w tym zakresie zmian, Wiadomości Ubezpieczeniowe nr specjalny 3/2013

M. Szczepańska, Wypłata wartości wykupu w umowie ubezpieczenia na życie z ubezpieczeniowym funduszem kapitałowym - charakter prawny świadczenia, Wiadomości Ubezpieczeniowe 3/2015, S. Włodyka w: S. Włodyka (red.), Prawo umów handlowych, Tom 5, Warszawa 2006, s. 48 -

M. Wiśniewski, Wartość wykupu polis życiowych z Ubezpieczeniowym Funduszem Kapitałowym, Wiadomości Ubezpieczeniowe 2/2012

\section{The issue of the application of Article $819 \S 1$ Civil Code to a redemption claim in the unit-linked life insurance contract}

The issue of the article concerns the application of Article $819 \S 1$ Civil Code to a redemption claim in the unit-linked life insurance contract. The analysis of the subject was presented in the broader context of the nature of the unit-linked life insurance contract and the life insurance contract. The article characterizes the insurer's benefits paid under these contracts. The article also discusses the issue of the application of unjust enrichment provisions to a claim for payment of a redemption claim.

keywords: Unit linked insurance, Life insurance, limitation period, Insurance contract, total or partial redemption claim

DR HAB. MAGDALENA SZCZEPAŃSKA - Kierownik Katedry Prawa Ubezpieczeń Uniwersytetu Warszawskiego. 
